\title{
Evaluation of Students' Remote Learning Experience of Learning Arabic as a Second Language During the Covid-19 Pandemic
}

\author{
Sultan Almelhes ${ }^{1}$ \\ ${ }^{1}$ Department of Teacher Preparation and Training, Islamic University of Medina, Saudi Arabia \\ Correspondence: Sultan Almelhes, Department of Teacher Preparation and Training, Islamic University of \\ Medina, Saudi Arabia.
}

Received: May 8, 2021

Accepted: July 4, 2021

Online Published: September 18, 2021

doi:10.5539/ies.v14n10p40

URL: https://doi.org/10.5539/ies.v14n10p40

\begin{abstract}
The emergence of the Covid-19 global pandemic was followed by restrictions on social contact and interaction. Online remote learning was implemented all levels of school and universities in Saudi Arabia. In tertiary education, where Arabic is taught as a second language (ASL) with extensive interaction between the teacher and students, remote learning has specific advantages and disadvantages. This study aimed to investigate the success of remote learning, its influence upon learners' attitudes, and its potential difficulties in implementation. Quantitative research was conducted on a sample of 236 students who had combined experiences of offline and online study during 2020 in their second semester at the Arabic Language Institute for Non-Native Speakers'. An online survey was administered consisting of three domains: students' satisfaction with remote learning, obstacles faced, and students' perceptions towards evaluation; students' responses were measured using a Likert scale. The results demonstrated that there was hesitation about student satisfaction, as the result was moderate in general. Moreover, the study revealed difficulties included internet connection issues, the access and availability of remote learning, insufficiency in personal expression, and difficulties with technological devices. The results also showed that the students were dissatisfied regarding to the evaluation and assessment methods used in remote learning.
\end{abstract}

Keywords: remote learning, e-learning, Arabic language as a second language, technology

\section{Introduction}

The process of second language acquisition is understood here as the process by which a speaker who has another language as his or her first language learns Arabic: Arabic is either spoken in the community where the learner lives or is a foreign language in that community. In 2020, teaching practice largely changed from face-to-face learning to remote learning due to the Covid-19 pandemic. There was a sudden restriction on face-to-face teacher-student interaction. As such, the educational system has been forced to dramatically change and higher education has been particularly severely affected. All education sectors in Saudi Arabia have transferred to remote learning, including of ASL institutions. According to the Saudi Arabia Communication and Information Technology Commission (CTIC), technology has grown rapidly in this country, specifically in relation to e-learning (Elfak, Abdulraheem, \& Abdulrahim, 2019, p. 226). However, this did not happen as a result of good preparation or a suitable infrastructure but came about as an emergency measure.

Technology has been used in learning for a time period (Alqarni, Bown, Pullen, \& Maters, 2020). Online programs have played a part in interactive education and virtual learning programs that have typically gone through a formal method of developing a virtual classroom, introducing it to students, and building a committed framework for supporting school-enrolled learners (Cleveland-Innes \& Garrison, 2020; Ray, 2020). In online learning or e-learning, multimedia resources are used to access the educational program beyond the standard classroom. Technology is a necessary element in the development of e-learning (Gros \& García-Peñalvo, 2016). Remote learning should be based on technical resources and provide general facilities for learner support. It demands preparation and because of varying requirements requires teacher preparedness. In remote learning, learners and teachers remain linked and involved in the learning process as they work from different locations. Learners usually work from home, but possibly also on occasion there are emergency situations that pose a challenge to learners' well-being (Ray, 2020). Saudi governance, according to the Seventh Development Plan, aims to improve higher education and provide learners with a suitable learning environment (Alqahtani, 2010). Saudi Arabia has invested 
in e-learning as a part of its educational reform, backed up by the adoption of communications technology (Aljaber, 2018; Alqahtani, 2010).

\section{Research Problem and Questions}

Until 2019, the Arabic Language Institute for Non-Native Speakers still depended mainly on traditional learning, with the teacher at the center of the educational process, though educational technology encouraged student self-reliance (Ganaym, 2006). However, the complete shutdown of Saudi universities due to Covid-19 in early 2020 meant a need to transition to online learning. E-learning had been planned for some time, but became a matter of emergency in education, with the implementation of different methods that would be challenging for students (Al-Hoshan, 2020; Ferri et al., 2020). The official platform Blackboard has been used for teaching ASL. Part of the scope of this study is to document Blackboard teaching to derive lessons for the future. Therefore, the research problem of this study lies in investigating how the remote learning of teaching the Arabic language to non-native speakers may influence students' learning attitudes. Thus, the three research questions of this quantitative study of ASL are:

1) What is the level of satisfaction of Arabic language learners with remote learning?

2) What are the difficulties that may hinder the optimal use of remote learning?

3) What are students' perceptions about the evaluation and assessment methods in remote learning?

Given the current circumstances of remote learning activity, the experiences of the non-native students are a critical component of this study. Their perceptions of their remote learning program will be significant in assessing the nature of any program of remote learning of ASL; their views on the use of technology in teaching may enable decision makers to understand the reality of the student experience; and the results of this study may help teachers and decision makers to understand critical areas in the teaching of Arabic.

\section{The Importance of the Study}

This research represents a contribution to exploring non-native students' perceptions regarding remote learning of ASL in higher education; student experiences are a critical component of this study. Moreover, because the study investigates the attitudes of students who are studying ASL, their opinions regarding the importance of using technology in teaching are important for decision makers to take into consideration to determine the reality of this experience. This study is also important because it may serve as a foundation for understanding the nature of remote learning in ASL. The findings may help decision makers to obtain a clear picture about the critical areas in relation to teaching Arabic. The results may also help teachers to understand students' perceptions as they are in constant contact with the students in order to overcome the challenges that they encounter. Moreover, although there are many studies addressing English second language acquisition through remote education, to my knowledge remote learning of ASL remains an under-researched area. For example, Mufidah, Bin-Tahir, and Islamy (2020) revealed that further research is needed to investigate the use of blended learning in teaching ASL.

\section{Theoretical Framework}

\subsection{What is Remote Learning?}

Online learning is a form of remote learning (Roberts, 2019), which allows learners to study off-campus. Remote learning uses different means and approaches to transfer learners' course content and learning, which could be spread across different areas of the world (Clark, 2020; Matthew, Sadiku, Philip, \& Sarhan 2018). Today, remote learning uses different measures to help teachers communicate with learners, such as daily email, high-tech assets such as the internet, and audio-video conferencing (Al-Hoshan, 2020). Thus, remote learning provides an opportunity for learning either synchronously or asynchronously (Abdul Raouf, 2015).

\subsection{The Role of the Teacher in Remote Learning}

\subsubsection{Technological Skills}

Technology has added value to remote learning and the education sector to a large extent (Ferri, Grifoni, \& Guzzo, 2020; Rybalko, Bukrieieva, \& Skrypnyk, 2020). The role of the teacher is to ensure that the technology presented to the students is appropriate for them, enabling them to carry out different activities that enhance their learning experiences (Friedrichsen, 2020; Kim, 2020). Thus, it is crucial that teachers have an adequate level of proficiency with technology to enable them to choose and use the appropriate technology (Johnson, Jacovina, Russell, \& Soto, 2016; Rapanta, Botturi, Goodyear, Guàrdia, \& Koole, 2020). Teachers should take advantage of technology to motivate students and stimulate their morale in learning (Stockwell, 2013). They should engage the students in several activities, including coordinating online student groups, ensuring the class has time for off-topic discussion, guiding the students to participate in interpersonal communication to increase their mutual 
connections in the class, and building morale regarding the learning process (Alawamleh, Al-Twait, \& Al-Saht, 2020). It is the teacher's role to help the students develop their learner autonomy in a manner which helps them succeed (Najeeb, 2013). For instance, they should help students identify their own learning needs, set learning objectives to address problems, identify resources, apply the appropriate learning strategies, and evaluate the learning outcomes (Chapelle \& Hegelheimer, 2004). This will help the students become more motivated and therefore learning will be more effective.

\subsubsection{Self-Regulation}

Students learning online have responsibility for their own learning (Compton, 2009; Mickan, McQueen, \& Lemhöfer, 2019). Therefore, it is crucial to create lesson plans to engage students and help them understand and retain important information, together with assigning and correcting homework, and giving students tests. The lesson plan includes the aims and objectives of the topic or course, describes the topic, and shows the activities to be undertaken during learning, which helps the teacher assign the work at the appropriate time planned for it (Rybalko et al., 2020). The teacher has a role in regulating the students' behavior, given that the learning process is long distance and therefore there is no face-to-face interaction (Lepp, Aaviku, Leijen, Pedaste, \& Saks, 2021). This is done by setting actions to follow in case of any breach of the students' rules. This can help the students to keep them focused on lessons (Rybalko et al., 2020). The teacher's roles are to ensure that the class has a good layout to help the students anticipate and also participate in the learning process. The teacher should be confident that the class layout can help in several ways, including but not limited to improving students' concentration and behavior, and helping to support more effective learning outcomes (Wandler \& Imbriale, 2021).

\subsubsection{Evaluation and Assessment Skills}

Evaluation and assessment are an integral part of educational system that led to evaluate students' progress. The teacher should have knowledge of different types of evaluation (Compton, 2009) because a good teacher may not necessarily have knowledge of different types and methods of evaluation and assessment. Evaluation is an inbuilt monitor used to review the progress in learning (Safer \& Fleischman, 2005). It provides desirability feedback on design and accomplishment. One-way students are guided to use what they already know and seek to add value to make elucidation. It requires collecting surveys and clarification of different particulars about any particular of a program of education or instruction as part of an acknowledged process of judging its success, efficiency, and any other consequences it may leave (Compton, 2009). Thus, the teacher should have knowledge of different types of evaluation (Compton, 2009) to choose the appropriate kind of technology that may be benefit (Chapelle, 2001). A study by Jaap, Dewar, Duncan, Karen, David, (2021) revealed that a most of students felt more nervousness during the e-examination because their concerns were related about technical issues. So, most students preferred the traditional examination compared to e-examination.Teachers should have a role of improving the learning process of the students. Evaluation helps generate valuable data about the imperfections in the lessons layout and performance system, which in turn enables lessons development in specified directions. Teachers should ensure that they give proper feedback to their students, given that it helps to increase students' confidence and to solve issues, and helps students understand the learning objectives; the learning process is made more interesting and engaging for both the students and the teacher (Friedrichsen, 2020). Teachers should understand that feedback does not equate to condemnation and therefore they should be critical in such a way as to ensure positive learning. The teacher can evaluate his/her learners via feedback, which can come in several forms, such as writing, video, photographs, verbal contact, and so on. Input comes in different modes and degrees of quality. Similarly, Krashen $(1982,1985)$ stresses that not only does any feedback contribute to the learning of vocabulary, but rather the input is at a much more sophisticated standard than what learners can actually comprehend or understand (Arrosagaray, González-Peiteado, Pino-Juste, \& Rodríguez-López, 2019; Kuama \& Intharaksa, 2016).

\subsection{Frameworks for Online Learning for Teaching a Second Language}

The first technical factor is the selection of a suitable Learning Management System (LMS), which is a web tool that delivers the substance of the course and provides learners with the course materials. The organization hosting the language course is the first location to search for an LMS (Guzachchova, 2020). Language instructors should weigh the following considerations when selecting an LMS: ease of access and navigation; technological support; capacity to include the required tools; ability to conceal unused tools; interactivity potential (e.g., whether it enables learners to embed information, build resources, and download and upload content, audio, and video); and potential for evaluating student learning (Kwon, Zhang, \& Vanden Bussche, 2020; Larsen-Freeman, 2018; Mosawy, 2018). A versatile addition to LMSs is web-conferencing software. These packages are becoming more common among individual educators who do not want to be limited by the LMSs 
used in their schools and want to use a platform that enables them to remotely reach their learners.

Efficient online foreign language courses can use a set of computer-mediated communication (CMC) resources to enable learners to communicate synchronously and asynchronously with other language speakers through text, audio, and/or video (Matthew et al., 2018). This approach is beneficial compared to the conventional face-to-face approach in that there is no restriction on learners and teachers' expected location (Cleveland-Innes \& Garrison, 2020; Matthew et al., 2018). As long as they have a screen, webcam, microphone, and broadband internet service, they can be situated anywhere. In line with the learner-centered learning philosophy, online classes are organized so that the teacher serves as a facilitator and mentor rather than a sage disseminating knowledge. Digital learning platforms, such as Moodle, WebCT, and Blackboard, have made it possible for faculty and learners to access material including documentation and web pages, and also to benefit from resources such as message forums, mail systems, and live chat. The main distinction between an online course and a correspondence course is the lack of contact between learners (Clark, 2020; Montiel-Chamorro, 2018) However, Pande (2018) found that courses heavily reliant on text-based multimedia were very inadequate in helping learners learn the language. Remote language learning issues include a lack of face-to-face contact, absence of teachers' body language, and technological problems. Potential technical difficulties and lack of technological experience could make lengthy tasks appear more complex and are likely to add to learners' dissatisfaction about the time taken to complete online tasks (Badhe, Badhe, \& Patil, 2020; Heppen et al., 2017; Musingafi, Mapuranga, Chiwanza, \& Zebron, 2015). Therefore, according to Kuimova, Burleigh, Uzunboylu, \& Bazhenov (2018), some learners assume that face-to-face learning is more powerful than remote learning.

\section{Related Studies in the Arabic Literature}

Due to the pandemic, remote learning has attracted the attention of teaching institutions to a great extent in current times. Regarding the teaching of second and foreign languages, remote learning or online courses is not a new concept: the popularity of these modes of learning peaked even before the 2020 Covid-19 pandemic. This was solely due to the high student demand for greater scheduling flexibility without being constrained by time and place (Blake, 2017). Many students who opt for online classes in a second language usually belong to the working class but need to obtain education in the second language while balancing work or family (Blake, 2017). Arabic language studies is primarily sought after by many native and non-native Muslims because of the relation of Arabic to the Holy Qur'an as the language of Allah (Almelhes, 2016) also, some poeple learn Arabic for various political, social and economic purposes (Sumi \& Sumi, 2018). For these reasons, the demand and need for learning the Arabic language is high and learning institutions have expended sufficient energy to facilitate the study of Arabic to meet this demand and the religious need for the language (Alowaydh, 2016). Electronic programs of learning have been supported to facilitate the remote learning of Arabic. Furthermore, according to Alowaydh (2016), another reason for opting for the remote learning of Arabic was a lack of student numbers and the need to fill this gap in the traditional Arabic language institutes. Arabic can be taught via a conventional learning system or via an electronic program of study (Elowaedy, 2016). With the increased need for remote learning, the desire to improve it in different countries, and its effect on educational institutes, studies evaluating the effectiveness of remote learning have been conducted (Alasraj \& Alharbi, 2014; Alwaleedi, 2020). Teaching second languages online using technology has now become common (Blake, 2017). Technological development and digital transformation have facilitated the delivery of online courses via remote learning (Dietrich et al., 2020)

Despite the existence of remote learning before the Covid-19 pandemic outbreak, this mode of learning became more prominent following the closure of schools to control and mitigate the spread of the virus (Fendler, 2021). There was a need to facilitate the continuation of education for students, which meant increasing the adoption of remote learning. According to Almelhes (2016), the transition from teacher-centered to student-centered learning has had many creative and positive impacts that have facilitated student success and created resilient faculties. For instance, physically challenged students have been given the freedom to participate easily in learning by requiring less movement than in face-to-face learning (Basilaia \& Kvavadze, 2020). Students and lecturers can interact and study virtually, even though they are physically and geographically separated (Fendler, 2021). A lot of research needs to be done to evaluate the effectiveness of this remote learning mode (Blake, 2017). Online learning comprises the individualization of learning, which further includes autonomy, accessibility, flexibility, and the use of various information and communication technologies instead of the traditional face-to-face mode of learning (Jost, Jossen, Rothen, \& Martarelli, 2021). Online learning and remote learning are usually implemented through online platforms; the use of any relevant and suitable outlet for online learning will depend on either the learners' or the teacher's expertise. These online platforms include Microsoft Teams, Google Classroom, Canvas, and Blackboard (Ahmadi \& Ilmiani, 2020). These platforms have made content sharing in many forms more convenient, which has eased the learning process, and further supported student learning and assessment through 
tests and the assessment of assignments.

Online learning has faced many challenges, including infrastructure, accessibility, affordability, flexibility, and educational policy (Pokhrel \& Chhetri, 2021). According to Pokhrel and Chhetri (2021), the learning experience is further hindered by unreliable internet connections, which is a problem faced by many countries, and limited access to digital devices and technology to access online learning of the Arabic language. This is especially the case for students that are economically disadvantaged, which has created a further gap in the educational system. Bahruddin and Ramadhanti (2020) also indicated that remote learning is significantly affected by internet limitations. Online learning is further characterized by a lack of parental guidance given that many parents are working. This has given children unlimited access to screen time, creating a high risk of exposure to unfiltered content that needs parental guidance (Pokhrel \& Chhetri, 2021). Online learning makes it difficult for students who need extra academic help to get it since there is limited supervision and guidance. The level of performance is likely to drop due to limited contact and no room for consultation (Sintema, 2020). Another factor that may affect the use of technology is the teachers' training. Integrating educational technology into classroom teaching practices necessitates preparing teachers professionally to enable them to use technology in the classroom (Balash, Yong, \& Bin Abu, 2011). Thus, some studies such as Alwani and Soomro (2010) and Bingimlas (2009) found that inappropriate instructional infrastructure significantly contributes to the optimal use of technology.

Ignorance of how to handle the technicalities of online learning has also plagued the learning of the Arabic language. Computer skills are a necessary skill for online learning that most students and teachers lack. However, there is no room for computer illiteracy (Abuhammad, 2020). Educators and students are expected to possess these skills and have some knowledge of web usage, search, and chatting over the internet so as to qualify for e-learning programs. A lack of these skills can significantly impact the submission of the various online assignments or tests online and online evaluation, which are indispensable elements of e-learning (Abuhammad, 2020). Despite the challenges hindering online learning, many previous studies indicated that technology positively influences language learning (Almelhes, 2016; Fendler, 2021). One way to measure the quality of education of online learning is to measure the learners' levels of satisfaction in learning (Gyamfi \& Sukseemuang, 2018). Regardless of the environment used, the quality of the delivery is crucial (Alzahrani, 2017). According to various researchers such as Huang and Wang (2012) and Gyamfi and Sukseemuang (2018), learners' satisfaction levels are often high when their expectations of the program and the study environment align, especially when the course design and teaching practices meet their expectations, and their learning achievement is good. Student satisfaction helps to improve learning as dissatisfied learners perform poorly (Gyamfi \& Sukseemuang, 2018).

To improve the quality of online learning, countries have evaluated the remote learning model, and evaluation studies on learner perceptions have been conducted (Alasraj \& Alharbi, 2014; Alwaleedi, 2020). Furthermore, the evaluation of student learning is a key aspect of this learning model. The evaluation process involves gathering and linking the relevant data to the target group and evaluation levels in two areas: diagnosing the weaknesses of the element under assessment and the strengths of the element under evaluation and offering recommendations and coming up with solutions to tackle the shortcomings (Alowaydh, 2016). It is crucial to maintain and be consistent in the monitoring and constant development of each curriculum item to take note of the strengths and shortcomings of the teaching methods. This can be done through observations, interviews, recordings, books, tests, conferences, individual/group meetings, and so on (Alowaydh, 2016). Gardner's socio-educational model for the Arabic language can be used to determine the attitude of remote learning students. Arifin, Jamsari, Riddzwan, Latif, and Halim (2014) used questionnaires and analyzed students' attitudes towards the learning environment. The study concluded that students have a positive attitude towards learning the Arabic language and an integrative orientation. Alwaleedi (2020) investigated how ASL learners collaborate in online collaborative writing. The results indicated participants' positive perceptions regarding the implementation of OCW. The study concluded that OCW has a positive impact on learner attitude, perceptions, and writing in Arabic learning.

\section{Methodology}

\subsection{Research Design}

The research study adopted a quantitative method of data analysis. The main rationale for this was that quantitative data concerning the online learning of the Arabic language using various forms of technologies would provide a clear view of student satisfaction and attitudes towards learning via remote education (Gharawi $\&$ Bidin, 2016). 


\subsection{Participants}

A total of 236 male students in semester 1 of 2020 were selected to participate in the study. They studied the first half of the semester via face-to-face learning while the second half was delivered through remote learning during the academic year of 2020. Thus, the students had two real experiences: face-to-face learning and remote learning. They took part in asynchronous study for each lesson every week during the semester. Asynchronous study was offered each week by the teachers of the class. Arabic lessons during the academic year were taught by 88 teachers from different classes who specialized in this field. The participating students ranged in age between 19 and 47 years. Regarding nationalities, the 236 participants were from 69 different nationalities divided into four levels, as shown in Table 1.

Table 1. Students' level of study

\begin{tabular}{ccc}
\hline Study level & Number of students & Percentage (\%) \\
\hline 1 & 9 & 3.8 \\
2 & 48 & 20.3 \\
3 & 68 & 28.8 \\
4 & 111 & 47.0 \\
Total & 236 & 100 \\
\hline
\end{tabular}

\subsection{Data Collection Instrument}

The research study used a survey as a data collection instrument to determine students' perceptions towards the remote learning of ASL. The survey included three domains. The first domain of the survey included ten items designed to assess students' satisfaction with remote learning of Arabic. The second domain was designed to present obstacles to remote learning and included ten items. The third domain included ten items that were designed to determine students' perceptions towards evaluation and assessment during remote study. The survey was translated and provided in four languages: Arabic, English, French, and Spanish, to ensure the accuracy of the responses. The survey items were presented on a five-point Likert scale: 1) Strongly agree; 2) Agree; 3) Neither agree nor disagree; 4) Disagree; 5) Strongly disagree.

\subsection{Procedure}

The survey was designed by the researcher after reviewing the relevant literature so that it would be constructed in a way that would measure the students' responses. The survey was initially designed and presented to a group of specialists to obtain feedback. It was then modified and edited based on the specialists' comments. To administer the survey to the participants, a link was sent initially to the teachers to pass on the link to the students. The link was also sent to some of the supervising students to send to their colleagues. Some students were also recruited to send the link to their colleagues from their own countries. The purpose of the survey and the value of students' cooperation were highly emphasized. Participants were asked to submit the survey once it was completed. The survey link was available from January 18, 2020, until February 11, 2020. The SPSS program was used to analyze the data gathered through the survey. For the interpretation of the data, the Oxford \& Burry-Stock (1995) scale was adopted to interpret the meaning of the scores, as presented in Table 2.

Table 2. Meaning of the scores

\begin{tabular}{cc}
\hline Range of mean scores & Meaning \\
\hline $1.0-2.4$ & Low \\
$2.5-3.4$ & Medium \\
$3.5-5$ & High \\
\hline
\end{tabular}

\subsection{Reliability and Validity}

\subsubsection{Validity}

After confirming the apparent validity of the survey according to the results of the arbitration, the researcher administered it to a random sample of 32 members from outside the research sample, in order to determine the validity of the internal consistency of the survey. The Pearson correlation coefficient was calculated between each domain and the overall score, as shown in Table 3. 
Table 3. Pearson correlation coefficients

\begin{tabular}{cccc}
\hline Survey domains & Item number & Pearson correlation & Sig (2-tailed) \\
\hline Satisfaction & 10 & $0.85^{* *}$ & 0.000 \\
Obstacles & 10 & $0.66^{* *}$ & 0.001 \\
Evaluation and assessment & 10 & $0.83^{* *}$ & 0.000 \\
\hline
\end{tabular}

**Correlation is significant at the 0.001 level (2-tailed).

Table 3 shows that all the values of the correlation coefficients between each domain and the total score of the survey are statistically significant at the 0.01 level, which demonstrates the internal consistency of the items and that they shared the concept of one measurement. This indicates that the survey has constructive validity and is valid for achieving the research aims.

\subsubsection{Reliability}

To ensure the reliability of the survey, the researcher used two methods: Cronbach's Alpha and the retest method.

i) Cronbach's Alpha equation: the equation was applied to the scores of the random survey sample consisting of 32 members. The results are shown in Table 4.

Table 4. Cronbach's Alpha results

\begin{tabular}{ccccccc}
\hline No. & Survey domains & Item numbers & Mean & Variance & Std. deviation & Cronbach's Alpha \\
\hline 1 & Satisfaction & 10 & 36.39 & 68.16 & 8.26 & 0.88 \\
2 & Obstacles & 10 & 34.48 & 89.53 & 9.46 & 0.92 \\
3 & Evaluation and assessment & 10 & 35.35 & 63.42 & 7.96 & 0.89 \\
& Overall & 30 & 106.22 & 393.27 & 19.83 & 0.92 \\
\hline
\end{tabular}

Table 4 shows that the survey has an appropriate degree of reliability, as the values of the alpha coefficients of the study domains ranged between 0.88 and 0.92 . The value of the alpha coefficient for the overall survey was 0.92 , indicating the reliability of the expected results after applying it to the sample.

ii) Retest method: the retest method was conducted twice on a group outside the study sample consisting of 32 members; the interval between the two tests was 21 days. The Pearson correlation coefficient was then calculated between their estimates at both times. To find the Cronbach alpha coefficient, the square root of the Pearson correlation coefficient was calculated; the results are shown in Table 5.

Table 5. Pearson's Alpha results

\begin{tabular}{ccccc}
\hline Survey domains & Item number & Pearson correlation & Sig(2-tailed) & Cronbach's Alpha \\
\hline Satisfaction & 10 & $0.85^{* *}$ & 0.000 & 0.92 \\
Obstacles & 10 & $0.93^{* *}$ & 0.000 & 0.96 \\
Evaluation and assessment & 10 & $0.90^{* *}$ & 0.000 & 0.95 \\
Overall & 30 & $0.94^{* *}$ & 0.000 & 0.97 \\
\hline
\end{tabular}

**Correlation is significant at the 0.001 level (2-tailed).

Table 5 shows that the correlation coefficient between the first and second applications of the survey was 0.97 for the total score of the survey, and the alpha values for the survey domains ranged between 0.83 and 0.92 .

The table also shows that all values of the correlation coefficient are statistically significant at the 0.001 level. This indicates that the reliability coefficients are appropriate and demonstrates the consistency of the internal items of the survey.

\section{Findings}

This section presents the survey results which were obtained from the 236 participants. 


\subsection{Students'Satisfaction with Remote Learning}

Table 6. Students' satisfaction with remote learning

\begin{tabular}{cccc}
\hline Sn. & Latent variable & Mean & SD \\
\hline 1 & The university provided us with sufficient qualifying training sessions on the use of & 2.4 & 1.152 \\
2 & remote learning & 2.3 & 1.160 \\
3 & The diversity of teaching methods used in remote learning. & 2.5 & 1.420 \\
4 & It was easy to transfer from traditional education to remote learning & 4.1 & 1.389 \\
5 & In general, I feel good about the use of remote learning systems & 3.3 & 1.224 \\
6 & It is easy to ask questions without feeling shy & 3.6 & 1.028 \\
7 & The university, in cooperation with the institute, provided many educational brochures on & 3.6 & 1.097 \\
8 & The Blackboard system provided by the university is easy to use & 2.9 & 1.128 \\
9 & The university and institute provided continuous technical support to facilitate the use of & Blackboard & 2.2 \\
10 & Wemote learning effectively contributed to the continuity of the educational classes & 1.202 \\
& Without interruption & 2.0 & 1.066 \\
\hline
\end{tabular}

Table 6 shows the means concerning the satisfaction level with remote education, which ranged from 2.0 to 4.1 . The overall mean suggests that students neither agree nor disagree with the items, which could mean they were undecided in their satisfaction level, and only three items received agreement (nos. 4, 6, and 7).

\subsection{Difficulties in Remote Education}

Table 7. Difficulties in remote education

\begin{tabular}{ccccc}
\hline Sn. & Latent variable & No & Mean & SD \\
\hline 1 & It is difficult to learn the Arabic language through remote learning & 236 & 3.71 & 1.263 \\
2 & Lack of internet access in some villages & 236 & 3.94 & 1.184 \\
3 & Frequent internet disconnection during study & 236 & 3.67 & 1.288 \\
4 & We do not have modern devices that help us to learn & 236 & 3.21 & 1.412 \\
5 & Lack of direct feedback & 236 & 3.48 & 1.197 \\
6 & Unavailability of the educational classes & 236 & 3.24 & 1.219 \\
7 & Remote learning does not provide space for personal expression & 236 & 3.47 & 1.290 \\
8 & There is a lack of collaborative learning & 236 & 3.49 & 1.277 \\
9 & There is no interaction among students & 236 & 3.62 & 1.355 \\
10 & Community does not accept the concept of remote learning & 236 & 3.22 & 1.365 \\
& & Mean 3.50 & .947 \\
\hline
\end{tabular}

Table 7 shows the means of obstacles in remote education, which ranged from 3.21 to 3.94. The overall mean suggests that the students agreed about the existence of these difficulties, and only three items indicate neither agreement nor disagreement (nos. 4, 6, and 10). 


\subsection{Students' Perceptions Towards Evaluation and Assessment}

Table 8. Students' perceptions towards evaluation and assessment methods

\begin{tabular}{ccccc}
\hline Sn. & Latent variable & No & Mean & SD \\
\hline 1 & Remote examinations are a convenient method to evaluate students & 236 & 3.18 & 1.388 \\
2 & Remote examinations are better than traditional examinations & 236 & 2.56 & 1.456 \\
3 & Students are evaluated with objectivity and credibility & 236 & 3.48 & 1.120 \\
4 & Diversity of methods of evaluation learning material & 236 & 3.51 & 1.074 \\
5 & There is continuous evaluation of students to ensure the achievement of learning outcomes & 236 & 3.44 & 1.134 \\
6 & All students are committed to attending examinations & 236 & 3.92 & .995 \\
7 & The educational lessons include exercises and assignments that help us to do exams & 236 & 4.04 & .949 \\
8 & The evaluation criteria are clear to me & 236 & 3.66 & 1.125 \\
9 & Remote learning helps in understanding the educational material clearly & 236 & 3.19 & 1.362 \\
10 & I receive the examination results immediately through the online examination & 236 & 3.78 & 1.186 \\
& & & Mean 3.48 & .845 \\
\hline
\end{tabular}

Table 8 shows the means of students' perceptions towards evaluation and assessment, which ranged from 2.56 to 4.04. The overall mean suggests that the students agreed in their perceptions towards evaluation and assessment, and only three items indicate neither agreement nor disagreement (nos. 1,2, and 9).

\section{Discussion}

RQ1: What is the level of satisfaction of Arabic language learners with remote education?

For RQ1, the results showed that the level of satisfaction of Arabic learners with remote education was neither high nor low (Overall mean $=2.9, \mathrm{SD}=.905)$, as shown in Table 6 . This shows that the learners were neither highly satisfied nor dissatisfied with remote learning. This implies that despite the university's ability to provide sufficient qualifying training sessions on remote learning and the diversity of teaching methods used in remote learning, it was still not enough to prepare the learners for the change from traditional face-to-face teaching to remote teaching. These difficulties revealed in the survey included limited access to a teacher for consultation and poor network communication, which made the learners feel less satisfied with remote education. This meant that learners have a low preference for online learning. This conclusion is like those by (Huang \& Wang, 2012; Gyamfi \& Sukseemuang, 2018), who indicated that students' satisfaction level in programs usually relates to fulfilling their expectations and meeting their needs; thus, it is probably the case that remote learning did not achieve their desires.

For RQ2, the table 7 revealed that the students found it difficult to learn the Arabic language through remote learning (Overall mean $=3.50, \mathrm{SD}=.947$ ) due to various obstacles that hindered the learning, including the lack of internet access in some villages, frequent internet disconnection during study, lack of modern devices that facilitate learning, failure to provide space for personal expression in remote learning, and many other obstacles. The biggest obstacle was the lack of internet access in some villages, as presented in item 2 (Mean $=3.94, \mathrm{SD}=$ 1.184). As revealed by the survey, learners were constrained by the lack of internet access to online learning and constant internet disconnections. The results of the survey align with those by (Musingafi et al., 2015; Pokhrel \& Chhetri, 2021; Bahruddin \& Ramadhanti, 2020), which showed that the lack of interest in using online learning programs was a result of problems related to the access and use of ICT including technical problems. In addition, the survey answers indicated that the students may have required assistance that was not immediately available.

In regard to RQ3, from the results under the table 8 revealed that students are not fully satisfied about evaluation methods used and they seem less enthusiastic about it as seen by its mean of (Mean $=3.48, \mathrm{SD}=.845)$. Research findings reveal that students are not fully satisfied about evaluation methods used and they seem less enthusiastic about it in comparison to in class examination. This may be attributed that we could not succeed in providing sufficient or appropriate methods to students about evaluation and assessment. Similar evaluation studies gauging student experience with online learning were carried out for an instance, by Alzahrani (2017) which was done to gauge student satisfaction with using online discussion forums at Saudi universities and an evaluation done by Jaap et al. (2021) to evaluate the e-examination which revealed that students preferred the traditional examination because the technical issues. Therefore, the student's reality and the current situation should be taken into consideration during the evaluation because evaluation is a crucial component when assessing the quality of education received. It is crucial to maintain and be consistent with the monitoring and development of 
students' progress through observations, tests, and individual or group meetings in addition to the technical support.

\section{Conclusions and Recommendations}

In conclusion, this study presents the current state of remote learning in teaching the Arabic language to non-native speakers in the Kingdom of Saudi Arabia. The study describes students' perceptions towards the educational system in relation to remote learning, together with the challenges they faced. Generally, students faced some challenges that resulted the students were completely dissatisfied with some elements of remote learning. To overcome the challenges faced by the students while learning the Arabic language via remote education, I would like to make the following recommendations:

1) Teachers should be aware of the theories of remote education and second language acquisition.

2) Students' differences should be considered in teaching and learning.

3) Different types of assessments to measure student progress should be used in various ways.

4) To ensure the quality of the learning, stakeholders should plan the study program well.

\section{References}

Abdul Raouf, T. (2015). E-learning and virtual education (1st ed.). Arab Group for Training and Publishing, Egypt.

Abuhammad, S. (2020). Barriers to distance learning during the COVID-19 outbreak: A qualitative review from parents' perspective. Heliyon, 6(11), 1-5. https://doi.org/10.1016/j.heliyon.2020.e05482

Ahmadi, A., \& Ilmiani, A. M. (2020). The use of teaching media in Arabic language teaching during covid-19 pandemic. Dinamika Ilmu, 20(2), 307-322. https://doi.org/10.21093/di.v20i2.2515

Al-Hoshan, A. (2020). Evaluating the distance learning experience during the corona pandemic using the multiple decision model (CIPP) -field study on students of Saudi universities. Journal of Educational and Psychological Sciences, 4(44), 61-81. https://doi.org/10.26389/AJSRP.L130620

Alasraj, A., \& Alharbi, H. (2014). The effectiveness of blended learning in teaching Arabic as a second language. International journal of research in humanities and social studies, 1(1), 13-17.

Alawamleh, M., Al-Twait, L., Al-Saht, G. (2020). The effect of online learning on communication between instructors and students during Covid-19 pandemic. Asian Education and Development Studies. https://doi.org/10.1108/AEDS-06-2020-0131

Aljaber, A. (2018). E-learning policy in Saudi Arabia: Challenges and successes. Research in Comparative and International Education, 13(1), 176-194. https://doi.org/10.1177/1745499918764147

Almelhes, S. (2016). Teaching of Arabic language proficiency (pronunciation) to non-native speakers: Designing interventions using ICT (Doctoral dissertation). Retrieved from https://researchdirect.westernsydney.edu.au/islandora/object/uws:38924/

Alowaydh, W. H. (2016). Evaluation of Arabic language learning program for non-native speakers in Saudi electronic university according to total quality standards. Journal of Education and Practice, 7(32), 74-90

Alqarni, A., Bown, A., Pullen, D., \& Maters, J. (2020). Mobile assisted language learning in learning Arabic as a second language in Saudi Arabia. Saudi Journal of Humanities and Social Sciences, 108-115. https://doi.org/10.36348/sjhss.2020.v05i02.009

Al-Qatawneh, S., Eltahir, M. E., \& Alsalhi, N. R. (2019). The effect of blended learning on the achievement of HDE students in the methods of teaching Arabic language course and their attitudes towards its use at Ajman University: A case study. Education and Information Technologies, 25(2), 1-27. https://doi.org/10.1007/s10639-019-10046-w

Alwaleedi, M. (2020). Online collaborative writing (OCW) in Arabic as a second language (ASL) classrooms: A mixed-method study. International Journal of Language and Literary Studies, 2(4), 266-279. https://doi.org/10.36892/ijlls.v2i4.459

Alwani, A., \& Soomro, S. (2010). Barriers to effective use of information technology in science education at Yanbu kingdom of Saudi Arabia, E-learning Experiences and Future. Retrieved from http://www.intechopen.com/books/elearning

Alzahrani, M. G. (2017). Student satisfaction with using online discussion forums at Saudi universities. World 
Journal of Education, 7(2), 1-10. https://doi.org/10.5430/wje.v7n2p1

Arifin, Z., Jamsari, E. A., Riddzwan, K., Latif, M. R. A., \& HALIM, Z. A. (2014). Attitudes of remote learning students at UKM's Faculty of Islamic Studies towards learning Arabic language skill courses. Turkish Online Journal of Remote Education, 15(1), 174-188. https://doi.org/10.17718/tojde.04949

Arrosagaray, M., González-Peiteado, M., Pino-Juste, M., \& Rodríguez-López, B. (2019). A comparative study of Spanish adult learners' attitudes to ICT in classroom, blended and remote language learning modes. Computers and Education, 134, 31-40. https://doi.org/10.1016/j.compedu.2019.01.016

Badhe, P., Badhe, Y., \& Patil, K. (2020). Comparison of distance learning with traditional classroom in medical college learners in Covid-19 lockdown period in India. Future of Medical Education Journal, 10(4), 42-45.

Bahruddin, U., \& Ramadhanti Febriani, S. (2020). Student's perceptions of Arabic online learning during COVID-19 emergency. Journal for the Education of Gifted Young Scientists, 8(4), 1483-1492. https://doi.org/10.17478/jegys.763705

Balash, F., Yong, Z., \& Bin Abu, B. (2011). Acceptance level of faculty members in utilizing educational technology tools. International Journal of Information and Education Technology, 1(5), 360-364. https://doi.org/10.7763/IJIET.2011.V1.58

Basilaia, G., \& Kvavadze, D. (2020). Transition to online education in schools during a SARS-Cov-2 coronavirus (COVID-19) pandemic in Georgia. Pedagogical Research, 5(4), 1-9. https://doi.org/10.29333/pr/7937

Bingimlas, K. (2009). Barriers to the successful integration of ICT in teaching learning environments: A review of the literature. Eurasia Journal of Mathematics, Science and Technology Education, 5(3), 235-245. https://doi.org/10.12973/ejmste/75275

Blake, R. (2017). Distance education for second and foreign language learning. In S. Thorne, \& S. May (Eds.), Language, Education and Technology. Encyclopedia of Language and Education (3rd ed.). Springer, Cham. https://doi.org/10.1007/978-3-319-02237-6_13

Chapelle, C. (2001). Computer applications in second language acquisition. Cambridge: Cambridge University Press. https://doi.org/10.1017/CBO9781139524681

Chapelle, C. A., \& Hegelheimer, V. (2004). The language teacher in the 21 st century. In S. Fotos, \& C. M. Browne (Eds.), New perspectives on CALL for second language classrooms (pp. 299-316). Mahwah, NJ: Lawrence Erlbaum Associates.

Clark, J. T. (2020). Distance education. In Clinical engineering handbook (pp. 410-415). Academic Press. https://doi.org/10.1016/B978-0-12-813467-2.00063-8

Cleveland-Innes, M., \& Garrison, R. (2020). An introduction to distance education: Understanding teaching and learning in a new era (2nd ed.). New York, Routledge. https://doi.org/10.4324/9781315166896

Compton, L. (2009). Preparing language teachers to teach language online: A look at skills, roles, and $\begin{array}{lllll}\text { responsibilities. } \quad \text { Computer Assisted } & \text { Language Learning, 22(1), }\end{array}$ https://doi.org/10.1080/09588220802613831

Dietrich, N., Kentheswaran, K., Ahmadi, A., Teychené, J., Bessière, Y., Alfenore, S., ... Hébrard, G. (2020). Attempts, successes, and failures of distance learning in the time of COVID-19. Journal of Chemical Education, 97(9), 2448-2457. https://doi.org/10.1021/acs.jchemed.0c00717

Elfak, N., Abdulraheem, I., \& Abdulrahim, R. (2019). Impact of e-learning vs traditional learning on students' performance and attitude. International Medical Journal, 8(10), 76-82. https://doi.org/10.36834/cmej.43447

Elowaedy, W. (2016). Evaluation of Arabic Language Learning Program for Non-Native Speakers in Saudi Electronic University According to Total Quality Standards. Journal of Education and Practice, 7(2), 74-90.

Fendler, R. J. (2021). Improving the "Other side" to faculty presence in online education. Online Journal of Distance Learning Administration, XXIV(1). Retrieved from https://www.westga.edu/ distance/ojdla/spring241/fendler241.html

Ferri, F., Grifoni, G., \& Guzzo, T. (2020). Online Learning and Emergency Remote Teaching: Opportunities and Challenges in Emergency Situations. Societies, 10(4), 1-18. https://doi.org/10.3390/soc10040086

Friedrichsen, A. (2020). Second language acquisition theories and what it means for teacher instruction 
(Master's thesis, Northwestern College, Iowa, USA). Retrieved from https://nwcommons.nwciowa.edu/cgi/viewcontent.cgi?article=1200\&context=education_masters

Gharawi, M. A., \& Bidin, A. (2016). Computer-assisted language learning for learning Arabic as a second language in Malaysia: Teacher perceptions. International Journal of Information and Education Technology, 6(8), 633-637. https://doi.org/10.7763/IJIET.2016.V6.764

Gros, B., \& García-Peñalvo, F. J. (2016). Future trends in the design strategies and technological affordances of e-learning. In M. Spector, B. B. Lockee, \& M. D. Childress (Eds.), Learning, Design, and Technology. An International Compendium of Theory, Research, Practice, and Policy (pp. 1-23). Switzerland: Springer International Publishing. https://doi.org/10.1007/978-3-319-17727-4_67-1

Guzachchova, N. (2020). Zoom technology as an effective tool for remote learning in teaching English to medical learners. Bulletin of Science and Practice, 6(5), 457-460. https://doi.org/10.33619/2414-2948/54/61

Gyamfi, G., \& Sukseemuang, P. (2018). EFL learners' satisfaction with the online learning program, tell me more. Turkish Online Journal of Distance Education, 19(1), 183-202. https://doi.org/10.17718/tojde.382798

Heppen, J. B., Sorensen, N., Allensworth, E., Walters, K., Rickles, J., Taylor, S. S., \& Michelman, V. (2017). The struggle to pass algebra: Online vs. face-to-face credit recovery for at-risk urban learners. Journal of Research on Educational Effectiveness, 10(2), 272-296. https://doi.org/10.1080/19345747.2016.1168500

Huang, K. S., \& Wang, T. P. (2012). An analysis of university freshman students' satisfaction in using on-line English practice exams. Journal of Global Business Management, 8(1), 139-147.

Jaap, A., Dewar, A., Duncan, C. Karen, F., David, H., \& David, K. (2021). Effect of remote online exam delivery on student experience and performance in applied knowledge tests. BMC Medical Education, 21(86), 1-7. https://doi.org/10.1186/s12909-021-02521-1

Johnson, A. M., Jacovina, M. E., Russell, D. E., \& Soto, C. M. (2016). Challenges and solutions when using technologies in the classroom. In S. A. Crossley, \& D. S. McNamara (Eds.), Adaptive educational technologies for literacy instruction (pp. 13-29). New York: Taylor \& Francis. Published with acknowledgment of federal support.

Jost, N. S., Jossen, S. L., Rothen, N., \& Martarelli, C. S. (2021). The advantage of distributed practice in a blended learning setting. Education and Information Technologies, 26, $3097-3113$. https://doi.org/10.1007/s10639-020-10424-9

Kim, J. (2020). Learning and teaching online during Covid-19: Experiences of student teachers in an early childhood education practicum. International Journal of Early Childhood, 52(2), 145-158. https://doi.org/10.1007/s13158-020-00272-6

Kuama, S., \& Intharaksa, U. (2016). Is Online learning suitable for all English language learners? PASAA: Journal of Language Teaching and Learning in Thailand, 52(6), 53-82.

Kuimova, M., Burleigh, D., Uzunboylu, H., \& Bazhenov, R. (2018). Positive effects of mobile learning on foreign language learning. TEM Journal, 7(4), 837-841.

Kwon, R., Zhang, M. L., \& Vanden Bussche, C. J. (2020). Considerations for remote learning in pathology during COVID-19 social distancing. Cancer Cytopathology, 128(6), 642-647. https://doi.org/10.1002/cncy.22289

Larsen-Freeman, D. (2018). Looking ahead: Future directions in, and future research into, second language acquisition. Foreign Language Annals, 51(1), 55-72. https://doi.org/10.1111/flan.12314

Lepp, L., Aaviku, T., Leijen, 1., Pedaste, M., \& Saks, K. (2021). Teaching during COVID-19: The Decisions Made in Teaching. Education sciences, 11(47), 1-21. https://doi.org/10.3390/educsci11020047

Matthew, S., Philip, A., \& Sarhan, M. (2018). Online teaching and learning. International Journal of Advanced Research in Computer Science and Software Engineering, 8(2), 73-75. https://doi.org/10.23956/ijarcsse.v8i2.549

Mickan, A., McQueen, J. M., \& Lemhöfer, K. (2019). Bridging the gap between second language acquisition research and memory science: The case of foreign language attrition. Frontiers in human neuroscience, 13, 397. https://doi.org/10.3389/fnhum.2019.00397

Montiel-Chamorro, M. L. M. (2018). Comparing online English language learning and face-to-face English language learning at el bosque university in Colombia (Doctoral dissertation, Virginia Commonwealth 
University, USA). Retrieved from https://scholarscompass.vcu.edu/cgi/viewcontent.cgi?article=6445\& context=etd

Mosawy, S. (2018). Current and emerging tools for flexible remote learning. In I. Singh, \& K. Raghuvanshi (Eds.), Emerging Technologies and Work-Integrated Learning Experiences in Allied Health Education (pp. 106-125). IGI Global. https://doi.org/10.4018/978-1-5225-3850-9.ch006

Mufidah, N., Bin-Tahir, S., \& Islamy, M. (2020). Blended learning approach in Arabic teaching for non-native speaker students. Conference: Proceedings of the 2nd International Conference on Quran and Hadith Studies Information Technology and Media in Conjunction with the 1st International Conference on Islam, Science and Technology. https://doi.org/10.4108/eai.2-10-2018.2295458

Musingafi, M., Mapuranga, B., Chiwanza, K., \& Zebron, S. (2015). Challenges for open and distance learning (ODL) students: Experiences from students of the Zimbabwe open university. Journal of Education and Practice, 16(18), 59-66.

Najeeb, S. (2013). Learner autonomy in language learning. Procedia-Social and Behavioral Sciences, 70, 1283-1242. https://doi.org/10.1016/j.sbspro.2013.01.183

Pande, J. (2018). Investigating the attitude towards the use of mobile learning in open and remote learning: A case study of Uttarakhand open university. The Online Journal of Distance Education and e-Learning, 6(4), 40-47.

Pokhrel, S., \& Chhetri, R. (2021). A literature review on impact of COVID-19 pandemic on teaching and learning. Higher Education for the Future, 8(1), 133-141. https://doi.org/10.1177/2347631120983481

Rapanta, C., Botturi, L., Goodyear, P., Guàrdia, L., \& Koole, M. (2020). Online university teaching during and after the Covid-19 crisis: Refocusing teacher presence and learning activity. Postdigital Science and Education, 2, 923-945. https://doi.org/10.1007/s42438-020-00155-y

Ray, K. (2020). What is remote learning? Retrieved from https://www.techlearning.com/how-to/what-is-remote-learning

Roberts, J. (2019). Online learning as a form of distance education: Linking formation learning in theology to the theories of distance education. HTS Teologiese Studies/Theological Studies, 75(1), 1-9. https://doi.org/10.4102/hts.v75i1.5345

Rybalko, I., Bukrieieva, O., \& Skrypnyk, N. (2020). The use of active learning methods to stimulate student activity in the online course. E-mentor, 4(86), 47-53. https://doi.org/10.15219/em86.1481

Safer, N \& Fleischman, S. (2005). Research matters/how student progress monitoring improves instruction. Educational leadership, 62(5), 81-83.

Sintema, E. (2020). Effect of COVID-19 on the performance of grade 12 students: Implications for STEM education. Eurasia Journal of Mathematics, Science and Technology Education, 16(7), 1-6. https://doi.org/10.29333/ejmste/7893

Stockwell, G. (2013). Technology and motivation in English-language teaching and learning. In E. Ushioda (Ed.), International Perspectives on Motivation. Palgrave Macmillan, London. https://doi.org/10.1057/9781137000873_9

Sumi, A. M., \& Sumi, K. (2018). Teaching and Learning Arabic in Japan. In K. Wahba, L. England, \& Z. A. Taha (Eds.), Handbook for Arabic Language Teaching Professionals in the 21st Century (Vol. II, pp. 20-37). New York: Routledge.

Wandler, J., \& Imbriale, W. (2017). Promoting undergraduate student self-regulation in online learning environments. Online Learning, 21(2), 1-6. https://doi.org/10.24059/olj.v21i2.881

\section{Copyrights}

Copyright for this article is retained by the author(s), with first publication rights granted to the journal.

This is an open-access article distributed under the terms and conditions of the Creative Commons Attribution license (http://creativecommons.org/licenses/by/4.0/). 